\title{
Ground-Air Interface: The Loess Sequences, Markers of Atmospheric Circulation
}

\author{
Denis-Didier Rousseau and Christine Hatté
}

\begin{abstract}
Atmospheric circulation is responsible for the rapid distribution of heat and moisture across the Earth and hence determines our weather and regional climate, today and in the past. During past climate cycles, the atmosphere has been much more dustier, except during the interglacials, inducing uncertainties about the impact of mineral aerosols on the past climate dynamics. There are abundant traces of the combination of past atmospheric dynamics and paleodust cycle such as eolian mineral material transported and deposited in terrestrial archives as loess. Records from loess deposits consistently suggest that atmospheric dynamics was highly variable, during the past climate cycles, much more than presently where the only sources of dust are the major deserts. In this chapter we explained the four main categories of parameters allowing to identify loess deposits as reliable markers for past air circulation.
\end{abstract}

\section{Overview of Loess}

Loess is an aeolian sediment which is relatively common in continental areas (Fig. 13.1). In Europe and North America, it is dispersed near former polar deserts or near the frontal

D.-D. Rousseau ( $\bowtie)$

École Normale Supérieure de Paris, Laboratoire de Météorologie Dynamique, UMR CNRS 8539, Université Paris Sciences et Lettres, 24 Rue Lhomond, 75231 Paris, France

e-mail: denis-didier.rousseau@lmd.ens.fr

Lamont-Doherty Earth Observatory of Columbia University, Palisades, NY 10964, USA

C. Hatté

Laboratoire des Sciences du Climat et de l'Environnement, LSCE/IPSL, Université Paris-Saclay, 91190 Gif-Sur-Yvette, France moraines of the gigantic ice sheets that developed on these continents during the ice ages. In Asia, however, the situation is different, since the Loess Plateau is located south of the deserts of northern China and southern Mongolia. The loess sediments thus cover vast regions of the northern hemisphere, at latitudes where very few other records of the glacial paleoclimates are available, while in more southern latitudes, lakes, peat bogs, speleothems and marine sediments collected close to the coast provide continental records of a high quality. In Southern Hemisphere, loess is mostly associated with fluvial and piedmont deposits in the Pampean plains in South America, and fluvial abrasion and glacial grinding in New Zealand.

Loess is a fine sediment transported mainly by wind to various altitudes depending on the particle grain size, but also on the state of the substratum and on the environmental conditions in the region of origin of the material (Fig. 13.2). Dust emission is favored by a low rate of vegetation development and extension of river-emerged banks, source of fine mineral dust. Loess deposits are thus specific to glacial times with low sea-levels thus high river incision and weak vegetation development.

To simplify, coarse material is carried over distances of less than hundred kilometers and transport is mainly by saltation, that is to say, by a series of jumps. However, fine material (clay), which may be of local or remote origins, may equally have been transported over hundreds of kilometers to altitudes of several kilometers in the form of mineral dust and may have been redeposited through wet or dry deposition (depending on whether or not they are associated with precipitations). Loess is therefore usually a marker for air circulation in the past.

To illustrate our words and the research potential of loess sequences, most of our examples will be drawn from the extensively studied Nussloch loess sequence (Rhine Valley, Germany). 


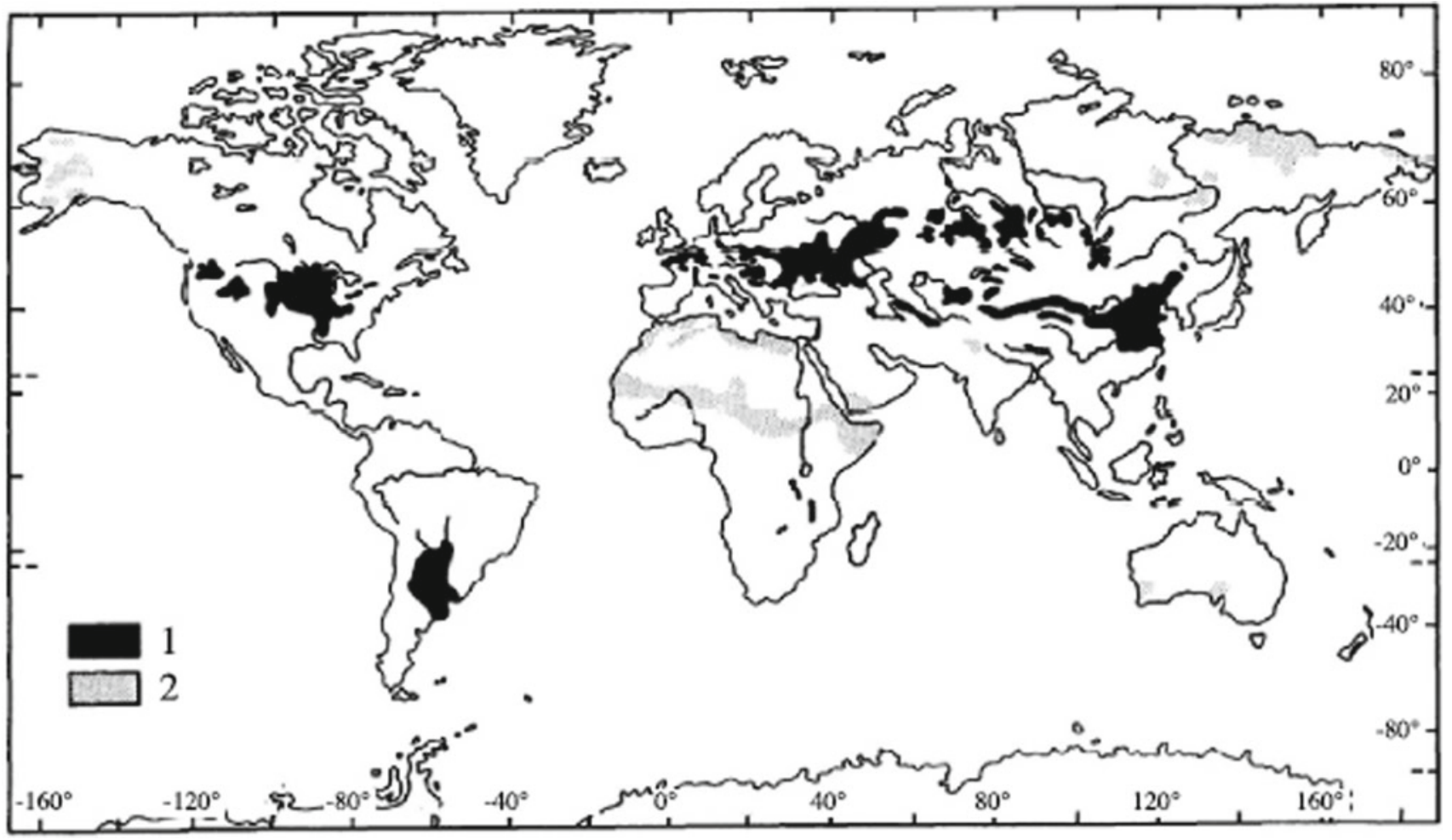

Fig. 13.1 Global distribution of loess sediments and equivalents. 1: loess sediments; 2: loess derivatives (according to Pécsi (1990))

\section{Paleoclimate Indicators}

Different paleoenvironmental indicators can be identified for this type of material, deposited at medium and high latitudes with climate conditions unfavorable for biological development (glacial periods). These parameters allow their interpretation in term of atmospheric circulation. Four major categories are presented below.

\section{Sedimentological Indicators}

\section{The conceptual view}

Even the observation of a loess sequence is instructive. Indeed, when a record is of one or more climate cycles, this is never made up of a single stratigraphic unit.

While loess sediment is characteristic of cold and quite arid periods, other warmer periods are marked by paleosols. Thus, if at low resolution, the loess-paleosol sequence corresponds to one or more climatic cycles; at higher resolution, the identification of more precise events is achieved by observing the sequence of soils or a particular hierarchy of pedo-sedimentary units. (Kukla and An (1989)). In Europe, a leached brown paleosol (Bt), at the base of a brown soil, indicates an interglacial level, while a humus-rich forest soil or a tundra gley (hydromorphic soil) are indicative of more temperate interstadial intervals (Antoine (2009)).

Since they present detailed records of past climate, reproducing the same pedostratigraphic and sedimentological units with the same succession of these units, the pedosedimentary record of loess sequences can be used as a powerful tool for chronostratigraphical correlation (Antoine, et al, (1999); Rousseau et al. (2007a, b)).

\section{The grain size index}

The study of the grain size, calculated through determination of the dominant classes, their mode distribution and relationships between them, can characterize the relative strengths of the winds that created the deposits (Rousseau et al. (2007a, b)). These wind dynamics are linked to changes in the general atmospheric circulation (Fig. 13.3). On a finer scale, Nussloch shows a progressive coarsening of the loess deposits between ca 30 and $22 \mathrm{ka}$ (Rousseau et al. (2007b)). This coarsening trend ends with a short but major decrease in grain size, followed by an increase to a new maximum at $20 \pm 2 \mathrm{ka}$ ("W" shape). Correlation between the loess grain-size index and the Greenland ice-core dust records suggests a global connection between North Atlantic and Western European global atmospheric circulation and wind regimes (Antoine (2009); Rousseau et al. (2007b)). 
Rapid transport of dust clouds over thousands of $\mathrm{km}$
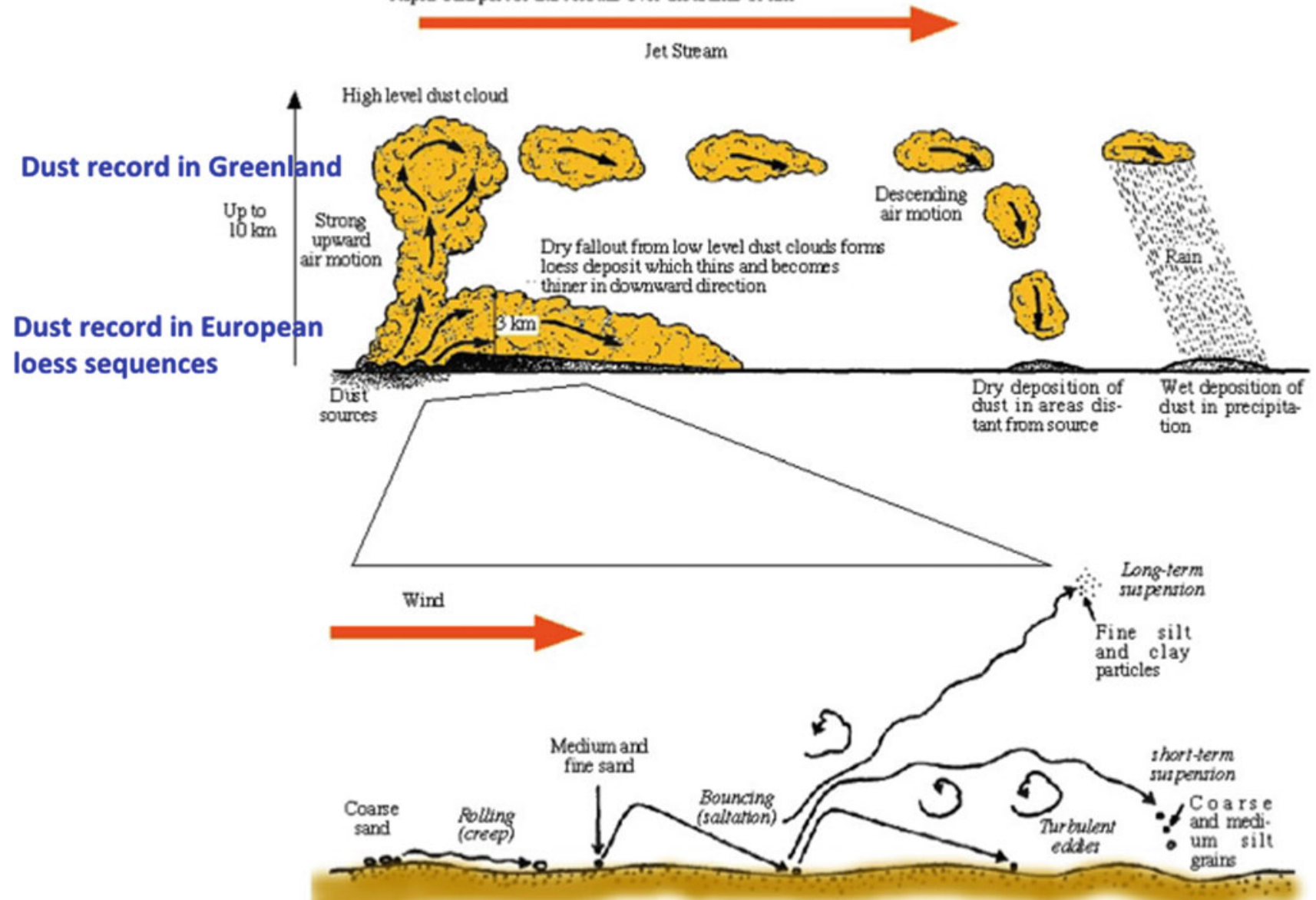

Fig. 13.2 Representation of the different types of dust transportation contributing to the formation of loess deposits. A-Two modes of transport and deposition of wind-blown dust from the northwestern deserts of China to the Loess Plateau and the North Pacific Ocean

\section{The loess deposit thickness}

The thickness of the units is another characteristic which also allows the link with wind dynamics to be established. Indeed, monitoring a particular unit in a given territory allows the characterization of gradients which will be oriented according to the prevailing winds, the thickest part being upwind (Rousseau et al. (2007a)) (Figure 13.4).

Furthermore, the cyclic variation of the sedimentation rate has been shown to be a potential response to the North-Atlantic rapid climate changes, i.e. the Greenland stadial/interstadial cycles and the Heinrich events. This hypothesis has been tested by modeling the impact of North-Atlantic climate variations on dust emissions. This study clearly highlighted that, besides wind, precipitation, soil moisture and snow cover showing some differences in the dust emission intensity, vegetation cover is the main impacting parameter (Sima et al. (2009)). Dust fluxes for the during the Quaternary (from Pye and Zhou (1989) modified). B - Diagram showing the various modes of transport of wind sediment particularly to the lower levels of the atmosphere (from Pye (1995) modified)

cold climate states (Greenland stadial and Heinrich event) generally become more than twice as high as those for the relatively warmer Greenland interstadial, in agreement with the observed loess data (Sima et al. (2009)) (Fig. 13.4).

\section{The mineralogy}

The mineralogy, in particular its composition of heavy minerals, also helps to trace the origin of certain deposits and to deduce the prevailing winds responsible for their transport (Lautridou (1985)).

\section{Biological Indicators}

These are relatively diverse. Although the remains of micro-mammals: bones, teeth or skulls, or of larger mammals are identified quite sporadically, other fossils are more 


\section{Groenland}

\section{Nussloch}

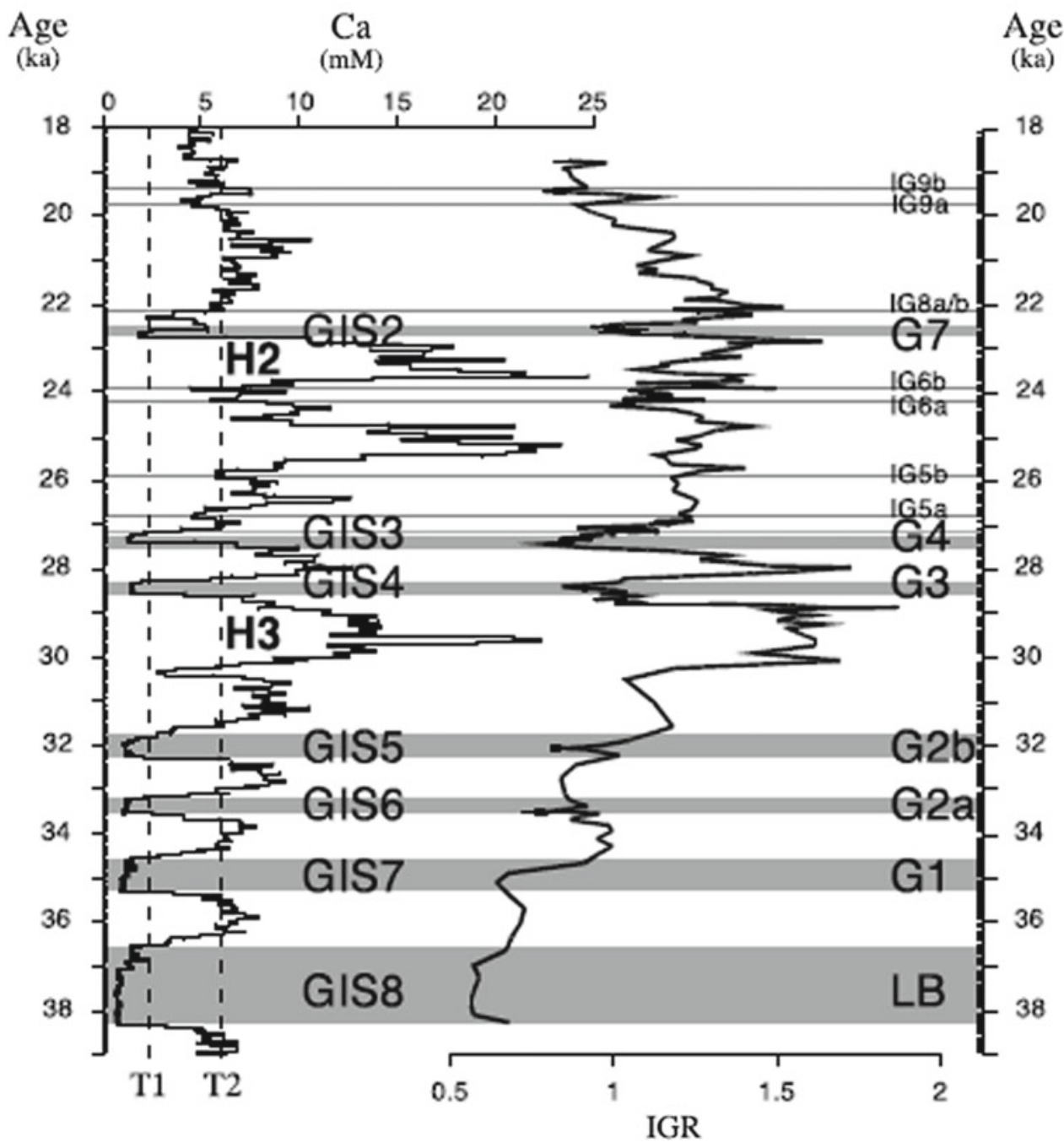

Fig. 13.3 Correlation of variations in particle size index (IGR) as defined at Nussloch with variations in calcium concentration (representing transported dust) from the GRIP survey. The T1 threshold applied to Greenland data highlights the main intervals with low dust concentration, which correspond to Dansgaard-Oeschger (DOI) interstadials 8 to 2 . These are correlated to intervals where the IGR is low in
Nussloch, corresponding to a brown boreal soil called Lohne Boden (LB) or to well-developed tundra gleys (G1, G2a, G2b, G3, G4 and G7). The T2 threshold defines intervals with very high dust concentration in Greenland, corresponding to the DO stadials, as well as some less significant peaks in dust (according to Rousseau et al. (2007b)) frequent. Among these, terrestrial mollusks form populations typical of diverse environments (Wu (2001); Rousseau (1987)).

\section{Mollusk assemblages}

Usually identified at the species level, these organisms have the advantage of persisting to the present day. In accordance with the principle of actualism, it is possible to apply modern requirements and ecological characteristics to individual fossils. Multivariate statistical analyses are used to reconstruct the environment in which a fossil community developed (Rousseau (1987)). Two examples follow: the first, in China, illustrates the long-term variations that can be correlated to terrestrial orbital frequencies and the second shows the short-term variation relating to the internal variability of the climate.

\section{The long-term variability}

Using the ecological requirements of taxa identified in the Chinese loess, it was possible to define environmental groups that have proven to be reliable indicators of the summer and winter monsoons through the ages (Fig. 13.5). Transfer 

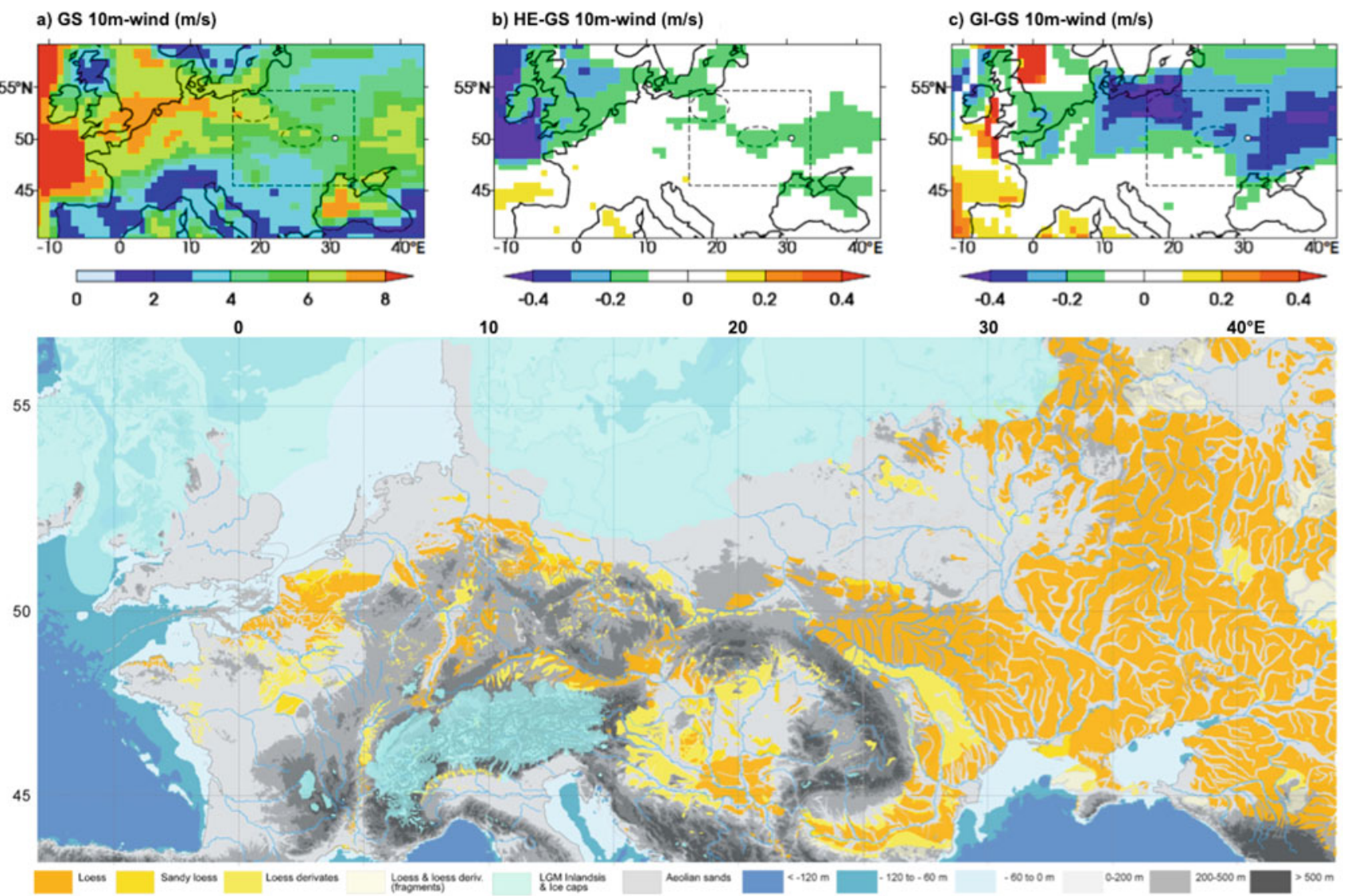

Fig. 13.4 Map of European loess deposits indicating the maximum expansion of the Fennoscandian and British ice sheets during the last glacial maximum (map by Antoine in [10] modified), with wind speed reconstructed for three climate conditions corresponding to northern oceanic influences: GS, HE-GS and GI-GS with GS = Greenland stadial, HE $=$ Heinrich stadial, GI-Greenland interstadial (according to Sima et al. (2009) modified) functions from terrestrial mollusks and using the principle of modern analogs, were developed to reconstruct the seasonal temperatures from the European loess sequences over three climate cycles (Rousseau (1991); Moine et al. (2002)).

\section{The short-term variability}

The high-resolution study (1 sample every $10 \mathrm{~cm})$ of malacological assemblages from the Nussloch loess sequence allows vegetation change to be described along the 70 to $34 \mathrm{kyr}$ cal BP period, recorded in 6 meters of sediment (Moine et al. (2005)). The mollusk changes reflect three short phases of vegetation development and climatic improvement related to soils of the interstadials. A steppe to herb/shrub tundra shift characterizes the Lower-Middle Pleniglacial transition and is followed by a decline in vegetation and humidity increase ending with a new increase in temperature and vegetation cover (Moine et al. (2005)).

Many other methods have been developed using micro-mammals or beetles, with the current distribution of species and the average ranges of associated climate acting as a reference (Liu et al. (1985)). Terrestrial mollusks have also been studied from their signature left in amino acids. This approach helps to distinguish important differences between one climate cycle and another (Oches and McCoy (1995)).

Another paleoclimate index also studied in loess sediments are phytoliths, siliceous concretions present in superficial plant tissue. In some cases, they are well preserved and identified, particularly in the Chinese loess sequences, where they helped in the reconstruction of the temperature and precipitation of the last climatic cycle ( $\mathrm{Lu}$ et al. (2007)). Pollen, in contrast, are poorly preserved in loess sequences and are the subject of very few studies (Gerasimenko and Rousseau (2008); Rousseau et al. (2001)).

Recently, earthworm granules have been established as a new biological proxy (Prud'homme et al. (2015)). This proxy is not based on species recognition but is based on abundance. Counts of earthworm granules reveal a link between their abundance and the nature of the stratigraphic units and their associated climate conditions. They are in very high abundances in tundra gley and boreal brown soil horizons, i.e. during Greenland interstadial intervals and are 


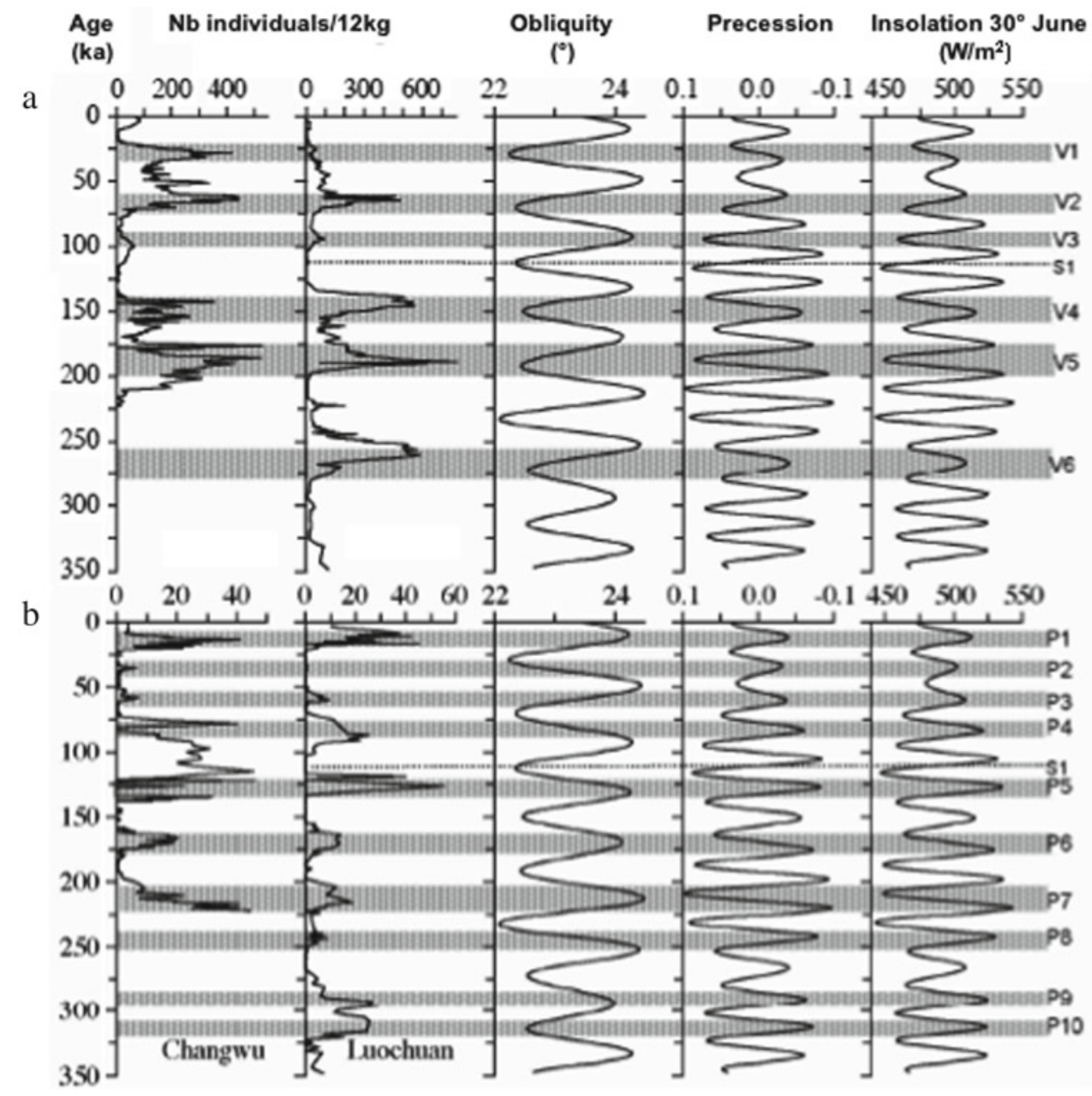

Fig. 13.5 Variations in the abundance of mollusks, characteristic of ancient summer and winter monsoons over the last three climate cycles in two sequences of the Chinese Loess Plateau (Changwu and Luochuan) and their relationship to astronomical parameters and

almost absent in typical calcareous loess, associated with Greenland and Heinrich stadials (Prud'homme et al. (2015)).

\section{Geophysical Indicators}

This is mainly the magnetic sensitivity in low fields which allows, firstly, the different lithological units present in the same sequence to be characterized, and secondly, to identify the source of the matter through the magnetic particle size (Lagroix and Banerjee (2002)). In general, typical loess units have relatively low field magnetic susceptibility, unlike paleosols, which are characterized by significantly higher values. Widely used for the Chinese sequences, low-frequency magnetic sensitivity was interpreted by Kukla et al. (1990) as corresponding to a relatively constant supply of fine matter through the ages. According to this theory, the formation of soil in the various Chinese interglacial insolation at $30^{\circ}$ N. A-Variations in the abundance of Vallonia tenera and Pupilla aeoli, indicators of ancient winter monsoons. BVariations in the abundance of Punctum orphana, indicator of ancient summer monsoons (according to Wu (2001)) paleosols caused the magnetic grains to become concentrated. This led Kukla to propose a chronological model, independent of any astronomical calibration, while assuming continuous and complete sequences. However, the discovery in the paleosols of bacteria secreting magnetic grains called this debatable assumption into question (Zhou et al. (1990)). On the other hand, research on modern Chinese soils along gradients, reflecting the impact of the summer monsoon, has enabled the calibration of the sensitivity signal and the establishment of a transfer function for the region to reconstruct annual paleoprecipitation associated with the variations in the East Asian monsoon (Maher and Thompson (1995)). A new method of characterizing the origin of loess is to work directly taking a quartz grain and to study both the crystallinity index and the intensity of the spin resonance signal. This new technique makes it possible to differentiate between the origins of the grains and thus to follow the variations in the source of the transported material. Applied 

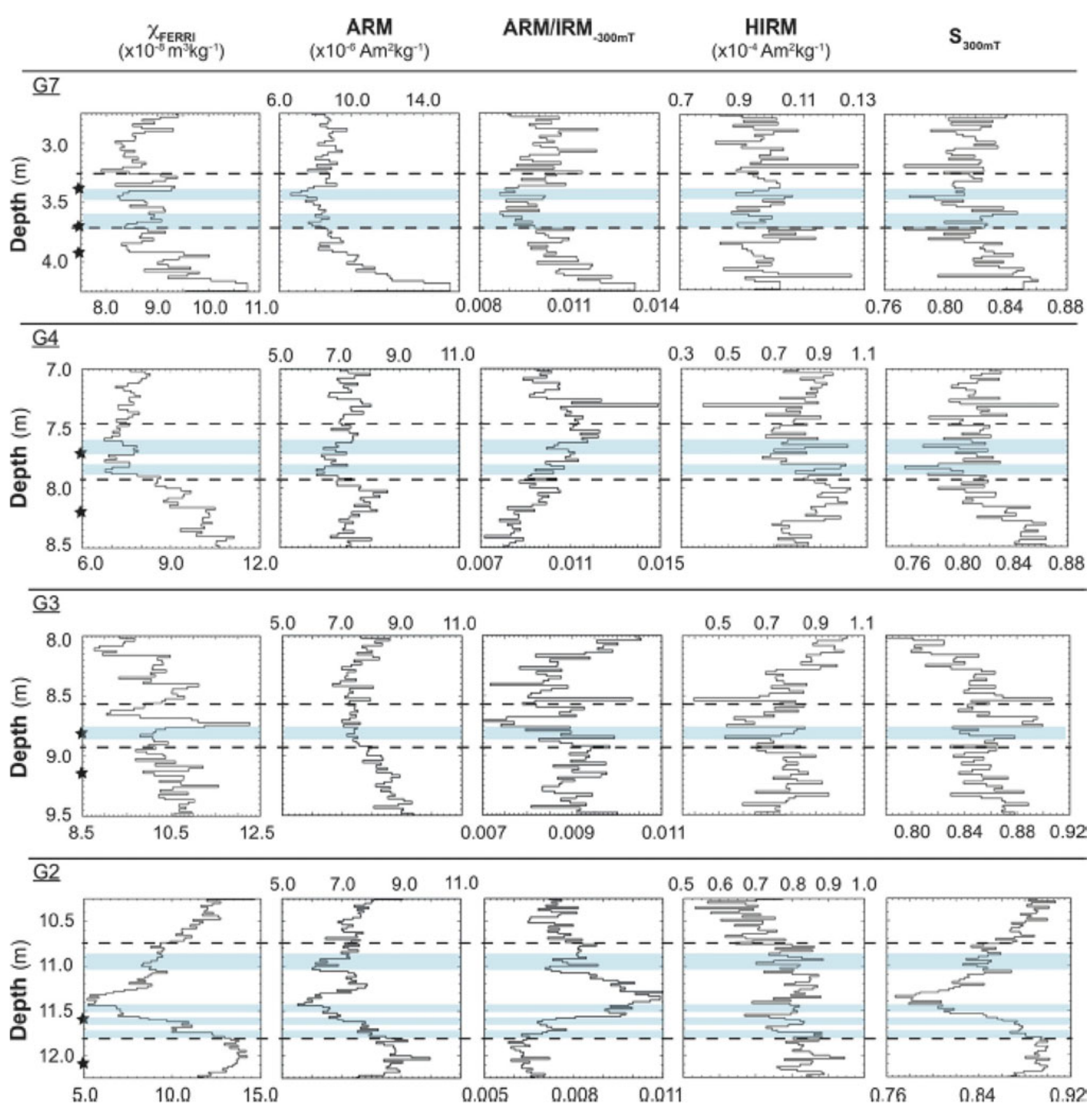

Fig. 13.6 Variation versus depth of rock magnetic parameters allowing the waterlogging in different tundra gleys from the Nussloch loess sequence to be characterized. From Taylor et al. (2014)

for the first time in the Chinese loess sequences, this method has helped to clarify the origin of the quartz grains transported to the Loess Plateau (the Gobi desert during stadial periods, deserts of northern China during the warmer periods) (Sun (2008)). More recently, the study of the mineral magnetic composition completed the classical interpretation of the magnetic susceptibility record by allowing waterlogging processes in tundra gley supporting the correlation of these paleosols with Greenland interstadials to be characterized (Taylor et al. (2014)) (Fig. 13.6).

\section{Geochemical Indicators}

The fourth category of indicators concerns geochemical indices and, in particular, isotopic parameters which constitute a powerful tool for interesting research perspectives.

\section{Tracing paleodust sources}

As representatives of the age of the geological formation, the dust particles derived from $\mathrm{Sr}$ and $\mathrm{Pb}$ isotopes are commonly 


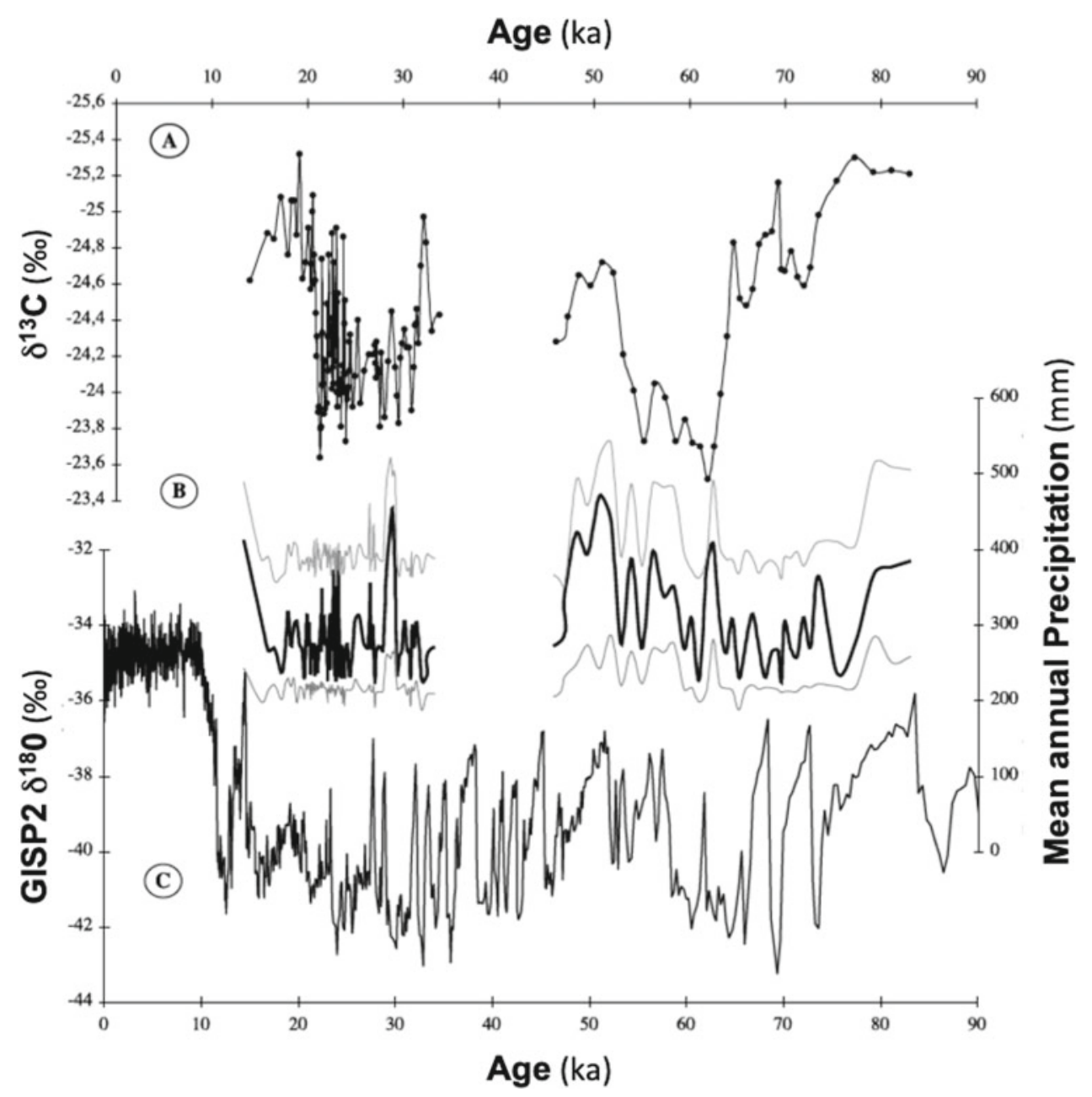

Fig. 13.7 Reconstructing the paleoprecipitation at Nussloch over the last $80 \mathrm{ka}$. $\mathrm{A}-\delta^{13} \mathrm{C}$ over time. The range of values obtained corresponds to plants of $\mathrm{C} 3$ photosynthetic type. B-Reconstruction of paleoprecipitation by inverse modeling of the isotopic signal (according to Hatté and Guiot (2005)). C-Comparison with $\delta^{18} \mathrm{O}$ in

regarded as source tracers. A recent study has been performed on loess samples, dated from the Last Glacial Maximum, located along a $50^{\circ} \mathrm{N}$ transect (from English Channel to Ukraine), chosen to represent the geographic and petrographic variability of the European loess belt. Geochemical results combined with dust emission simulations revealed that the dust was transported only over a few hundred kilometers. Moreover, the results highlighted that the sources were regional and that distinct sources prevailed within the European continent (Rousseau et al. (2014)).

\section{Tracing past precipitation and seasonality}

The analysis of $\delta^{13} \mathrm{C}$ from organic matter preserved in very small quantities in the loess sediment indicates the presence of vegetation; this can also be observed through the presence
Greenland ice (GISP2). During periods of high sea level, the warm phases of DO events result in a net increase in rainfall (+30 to $40 \%$ ), while during periods of low sea level, the distance from the coastline insulates Nussloch from any climatic improvement that might result from a warm episode of carbonated concretions developed around herbaceous rootlets (for example, Wang and Follmer (1998); Hatté et al. (2001a)). The values of this isotopic ratio also allow the characterization of the type of vegetation which trapped the dust during its deposition, and therefore the associated environmental and climatic conditions. Distinctions may be made at the level of the photosynthetic cycle (plants in C3 compared to those in C4) or within a similar photosynthetic type through the definition of seasonal variations in temperature or precipitation.

The inversion of vegetation models incorporating an isotopic fractionation module allows the reconstruction of fluctuations in the annual rainfall patterns occurring during the deposition of the sequence (Hatté and Guiot (2005)) (Fig. 13.7). Analysis of other chemical elements, such as rare earth elements, or other isotopes, contributes to the 


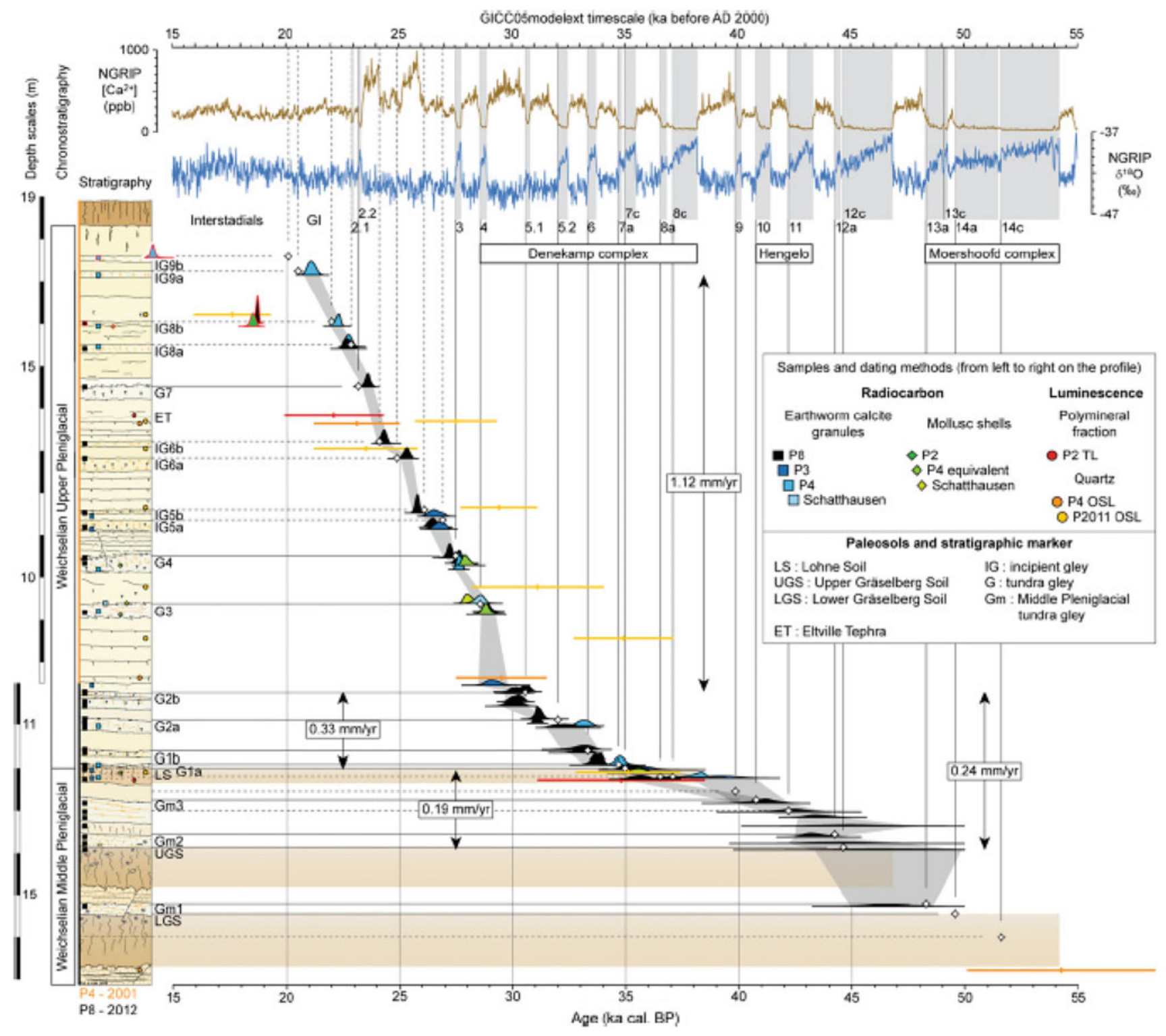

Fig. 13.8 ${ }^{14} \mathrm{C}$ dates obtained from earthworm granules collected in the different paleosols from the Nussloch sequence. Correlation with the NGRIP climate changes described by the dust and the $\delta^{18} \mathrm{O}$ variations from Moine et al. (2017)

search for the origin of the transported matter, using samples taken from potential source areas, and thus, to estimate the transport-related mechanisms (Rousseau et al. (2014); Gallet et al. (1996); Guo et al. (2002)).

\section{Tracing past precipitation and past temperature}

At the same time as the abundance count of earthworm calcitic granules emerged as a paleoclimate proxy, study of their isotopic properties has also developed (Prud'homme et al. (2016), (2018)). The $\delta^{18} \mathrm{O}$ granules and interlinked transfer functions between water cycle, air and soil temperatures allow the estimation of air temperatures. In Nussloch, the mean summer air temperature during Greenland interstadial has been estimated to have been $10-12 \pm 4{ }^{\circ} \mathrm{C}$ (Prud'homme et al. (2016)). In line with loess organic $\delta^{13} \mathrm{C}$ interpretation, $\delta^{13} \mathrm{C}$ of earthworm granules has been interpreted as a proxy of paleoprecipitation. Thanks to transfer functions, the past precipitation in Nussloch during the Greenland interstadial has been estimated at about 159$574 \mathrm{~mm} / \mathrm{yr}$ (Prud'homme et al. (2018)).

\section{Loess Chronology}

Loess chronology remains a major challenge since OSL returns a wide range of value depending on the choice of the mineral (type and grain size), the choice of light ray (IRSL, 
OSL,), and the analytical choice to reconstruct the evolution through time of the ambient dose rate. Nevertheless, it provides a reliable frame allowing comparisons with speleothem or ice-core chronologies (Lang et al. (2003); Fuchs et al. (2013); Rousseau et al. (2013)).

${ }^{14} \mathrm{C}$ is limited by its $50-0$ kyr range and by the fact that reliable supports such as charcoal or wood are rare in loess sequences. Trials on ubiquitous supports (loess OM bulk (Hatté et al. (2001b)) and alkane (Häggi (2014)) were not that conclusive, highly dependent on the status of the loess section studied and on the cleaning method of the outcrop. Even in the best conditions, they show poor reliability around (paleo) soil. However, the ${ }^{14} \mathrm{C}$ dates obtained from the calcitic earthworm granules allow perfect dating of the various paleosols (embryonic soils, tundra gleys and arctic brown paleosols) from which they are collected, as was recently demonstrated in the Nussloch sequence (Fig. 13.8) (Moine et al. (2017)). This new approach opens the door to precise and independent chronologies of loess sequences.

\section{References}

Antoine, P., et al. (1999). Last interglacial-glacial climatic cycle in loess-palaeosol successions of north-western France. Boreas, 28, 551-563.

Antoine, P., et al. (2009). Rapid and Cyclic Aeolian Deposition During the Last Glacial in European Loess: A High-Resolution Records from Nussloch, Germany. Quaternary Science Reviews, 28, 2955 2973.

Fuchs, M., et al. (2013). The loess sequence of Dolni Vestonice, Czech Republic: A new OSL based chronology of the Last Climatic Cycle. Boreas, 42, 664-677. https://doi.org/10.1111/j.1502-3885.2012. 00299.x.

Gallet, S., et al. (1996). Geochemical characterization of the Luochuan Loess-Paleosol sequence, China, and Paleoclimatic Implications. Chemical Geology, 133, 67-88.

Gerasimenko, N., \& Rousseau, D.-D. (2008). Stratigraphy and Paleoenvironments of the Last Pleniglacial in the Kyiv Loess Region (Ukraine). Quaternaire, 19(4), 293-307.

Guo, Z. T., et al. (2002). Onset of Asian desertification by $22 \mathrm{Myr}$ ago inferred from loess deposits in China. Nature, 416, 159-163.

Häggi, C., et al. (2014). On the stratigraphic integrity of leaf-wax biomarkers in loess paleosols. Biogeosciences, 11, 2455-2463. Pécsi, M. (1990). Loess Is not just the accumulation of dust. Quaternary International, 7/8, 1-21.

Hatté, C., et al. (2001a). $\delta^{13} \mathrm{C}$ Variation of loess organic matter as a potential proxy for paleoprecipitation. Quaternary Research, 55, 33-38.

Hatté, C., et al. (2001b). Development of an accurate and reliable ${ }^{14} \mathrm{C}$ chronology for loess sequences. Application to the loess sequence of Nußloch (Rhine valley, Germany). Radiocarbon, 43, 611-618.

Hatté, C., \& Guiot, J. (2005). Palaeoprecipitation reconstruction by inverse modelling using the isotopic signal of loess organic matter: application to the Nussloch Loess Sequence (Rhine Valley, Germany). Climate Dynamics, 25, 315-327.

Kukla, G., et al. (1990). Magnetic susceptibility record of Chinese Loess. Transactions of the Royal Society Edinburgh: Earth Sciences, 81, 263-288.
Kukla, G. J., \& An, Z. S. (1989). Loess stratigraphy in central China. Palaeogeography, Palaeoclimatology, Palaeoecology, 72, 203225.

Lagroix, F., \& Banerjee, S. K. (2002). Paleowind directions from the magnetic fabric of loess profiles in Central Alsaka. Earth and Planetary Science Letters, 195, 99-112.

Lang, A., et al. (2003). High-resolution chronologies for loess: Comparing AMS ${ }^{14} \mathrm{C}$ and optical dating results. Quaternary Science Reviews, 22, 953-959.

Lautridou, J. P. (1985). Le Cycle Périglaciaire Pléistocène en Europe $d u$ Nord-Ouest et plus particulièrement en Normandie (pp. 908). Centre Géomorphologie Caen: Thèse Etat, Université Caen, Caen.

Liu, T. S., et al. (1985). Loess and the environment (pp. 251). Beijing: China Ocean Press.

Lu, H. Y., et al. (2007). Phytoliths as quantitative indicators for the reconstruction of past environmental conditions in China II: Palaeoenvironmental reconstruction in the loess plateau. Quaternary Science Reviews, 26, 759-772.

Maher, B. A., \& Thompson, R. (1995). Paleorainfall reconstructions from pedogenic magnetic susceptibility variations in the Chinese Loess and Paleosols. Quaternary Research, 44, 383-391.

Moine, O., et al. (2002). Paleoclimatic reconstruction using mutual climatic range on terrestrial mollusks. Quaternary Research, 57, $162-172$.

Moine, O., et al. (2005). Terrestrial molluscan records of Weichselian Lower to Middle Pleniglacial climatic changes from the Nussloch loess series (Rhine Valley, Germany): the impact of local factors. Boreas, 34, 363-380.

Moine, O., et al. (2017). The impact of Last Glacial climate variability in west-European loess revealed by radiocarbon dating of fossil earthworm granules. Proceedings of the National Academy of Sciences, 114, 6209-6214.

Oches, E. A., \& McCoy, W. (1995). Amino Acid geochronology applied to the correlation and dating of central European loess deposits. Quaternary Science Review, 14, 767-782.

Pécsi, M. (1990). Loess is not just the accumulation of dust. Quaternary International, 7(8), 1-21.

Prud'homme, C., et al. (2015). Earthworm calcite granules: a new tracker of millennial-timescale environmental changes in Last Glacial loess deposits. Journal of Quaternary Science, 30, 529-536.

Prud'homme, C., et al. (2016). Palaeotemperature reconstruction during the Last Glacial from $\delta^{18} \mathrm{O}$ of earthworm calcite granules from Nussloch loess sequence, Germany. Earth and Planetary Science Letters, 442, 13-20.

Prud'homme, C., et al. (2018). $\delta^{13} \mathrm{C}$ of earthworm calcite granules: a new proxy for palaeoprecipitation reconstructions during the Last Glacial in Western Europe. Quaternary Science Reviews, 179, 158166.

Pye, K. (1995). The nature, origin and accumulation of loess. Quaternary Science Reviews, 14, 653-667.

Pye, K., \& Zhou, L. P. (1989). Late Pleistocene and Holocene Aeolian Dust Deposition in North China and the Northwest Pacific-Ocean. Palaeogeography, Palaeoclimatology, Palaeoecology, 73, 11-23.

Rousseau, D.-D. (1987). Paleoclimatology of the Achenheim Series (Middle and Upper Pleistocene, Alsace, France). A Malacological Analysis. Palaeogeography, Palaeoclimatology, Palaeoecology, 59, 293-314.

Rousseau, D.-D. (1991). Climatic transfer function from quaternary mollusks in european loess deposits. Quaternary Research, 36, 195209.

Rousseau, D.-D., et al. (2001). Late Pleistocene environments of the central Ukraine. Quaternary Research, 56, 349-356.

Rousseau, D.-D. et al. (2007a). Evidence of cyclic dust deposition in the US great plains during the last deglaciation from the high-resolution analysis of the peoria loess in the eustis sequence 
(Nebraska, USA). Earth and Planetary Science Letters, 262, 159174.

Rousseau, D.-D. et al. (2007b). Link Between European and North Atlantic Abrupt Climate Changes over the Last Glaciation. Geophysical Research Letters, 34, https://doi.org/10.1029/ $2007 \mathrm{gl} 1031716$.

Rousseau, D. D., et al. (2013). Major dust events in Europe during marine isotope stage 5 (130-74 ka): A climatic interpretation of the 'markers. Climate of the Past, 9, 2213-2230.

Rousseau, D.-D., et al. (2014). European Glacial Dust Deposits: Geochemical Constraints on Atmospheric Dust Cycle Modeling. Geophysical Research Lettters, 41, 7666-7674. https://doi.org/10. 1002/2014GL061382.

Sima, A., et al. (2009). Imprint of North-Atlantic millennial-timescale variability on Western European loess deposits as viewed in a dust emission model. Quaternary Science Reviews, 28, 2851-2866.
Sun, Y. et al. (2008). Tracing the provenance of fine-grained dust deposited on the central Chinese loess plateau. Geophysical Research Letters, 35. https://doi.org/10.1029/2007GL031672.

Taylor, S. N., et al. (2014). Mineral magnetic characterization of the Upper Pleniglacial Nussloch loess sequence (Germany): an insight into local environmental processes. Geophysical Journal International, 199, 1463-1480.

Wang, H., \& Follmer, L. R. (1998). Proxy of monsoon seasonality in carbon isotopes from paleosols of the Southern Chinese loess plateau. Geology, 26, 987-990.

Wu, N. Q. et al., (2001). Orbital forcing of terrestrial mollusks and climatic changes from the loess plateau of China during the past 350 ka. Journal of Geophysical Research-Atmospheres, 106, 20 045-20054.

Zhou, L. P., et al. (1990). Partly Pedogenic Origin of Magnetic Variations in Chinese Loess. Nature, 346, 737-739. 